\title{
'Walking in the light' and the missio Dei: Perspectives from the Anglican Church of Kenya
}

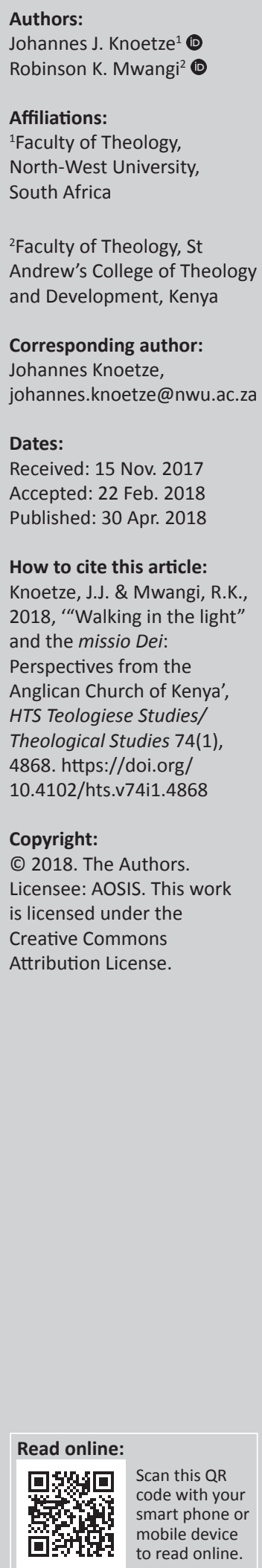

The East African Revival Movement's (EARM) socio-ethical belief and practice of walking in the light pervades mainstream Protestant churches in Eastern Africa with its emphasis on public confession of sin, which breeds severe relational consequences. Indeed walking in the light of the EARM has long plagued the Anglican Church of Kenya's participation in the missio Dei, which brings to the fore two categories of Christians, the saved and unsaved. While walking in the light has been buttressed in the Anglican Church of Kenya it is critical to recognise that the mission of God ought to be the heartbeat of the EARM's very existence. Accordingly, this article demonstrates that it is not the church that has a mission, but the Triune God that challenges the place of walking in the light in the Trinitarian God. This study, therefore, champions practical holiness by positioning walking in the light in the mission of God. As a result, it redefines the EARM's religious identity, illustrated by a proper exposition of scripture, Trinitarian worship, discreet confession of sin and moral legalism that provides for informed evangelism and social responsibility.

\section{Introduction}

This article specially elucidates the concept of walking in the light in the East African Revival Movement (EARM) in the Anglican Church of Kenya and in the missio Dei. Though initially the EARM had infiltrated the Anglican Church in East Africa in the early 20th century, it nevertheless later was attracted to other mission churches like Methodist and Presbyterian. The movement brought together a significant number of adherents from all these churches. This study investigates the EARM in the Anglican Church, viewing the relationship between the two as that of a daughter to a mother. Thus, the term 'EARM' is not a synonym for either the Anglican Church or any other but represents a fellowship that cuts across the Protestant mission churches in the East African region. This article focuses mainly on Kenya, which is one of the East African countries ${ }^{1}$ adversely influenced by the EARM. In Kenya, the movement is commonly referred to as 'Brethren Fellowship'.

To place walking in the light in its proper perspective, a contextual definition and description is necessary before situating it in the missio Dei.

\section{Contextual definition of 'walking in the light'}

The phrase 'walking in the light' as used by the members of the EARM refers to a daily sanctification that is attained by a life of daily walking with the Lord and a regular examination of one's heart and repentance (Gitari, n.d.:2). Ward and Wild-Wood (2012:215) seem to concur with Gitari in their statement that walking in the light means being transparent and open with one another. In spite of its somewhat erroneous theological background, walking in the light has had a profound influence on the EARM's socio-ethical belief and practice. To grasp the strength of this force something more elaborate and descriptive than a definition is required.

\section{Contextual description of 'walking in the light'}

Bruner (2012) gives one of the most profound descriptions of the phrase 'walking in the light' from the perspective of the EARM:

[T] he Balokole ${ }^{2}$ [Brethren] believed that spiritual darkness shrouded sinful secrets, and they worked to bring these secrets to the light. They believed that sins must be exposed through public confession, and

1.The countries that comprise East Africa are Sudan, South Sudan, Eretria, Ethiopia, Seychelles, Kenya, Uganda, Tanzania, Rwanda and Burundi. Among these, Kenya, Uganda, Tanzania, Rwanda and Burundi are the main setting of the EARM because of their historical contact with the Keswick movement.

2.This term refers to the 'saved ones' in Luganda and is synonymous with 'Brethren', a term widely used in Kenya to allude to members of the EARM. 
revivalists developed a lifestyle of making public those sins. They called this way of life 'walking in the light' (okutambulira mu musana). (p. 256)

Gitari (n.d.:2) asserts that Brethren will know that one is living a sanctified life when one attends fellowship meetings regularly, testifies about his trials and temptations, and walks in the light. The weekly fellowship meeting gives each person an opportunity to share with the Brethren the kind of life he has lived since the last fellowship meeting. Because they consider the devil to be always at war with believers, the testimony must include a statement of the temptations one has gone through and the way he has turned to Jesus for victory. This, in a nutshell, is what it means to walk in the light from the Brethren's point of view. If one's lifestyle is to the contrary, one may be declared as no longer saved. Furthermore, Brethren who have nothing to say during a fellowship meeting may cause concern and might even be declared lukewarm or spiritually cold.

As a result, public testimony and confession have become the most enduring phenomenon of the EARM achieved by walking in the light, albeit they are sometimes contentious and confrontational. This phenomenon is controversial because of a tendency to confess past misdeeds that might breed serious relational consequences with the aggrieved member of the community who hitherto had no information of betrayal until then. It could also prove confrontational. For instance, the Principal of Crowther Hall, Birmingham, utterly unaware of the revival practice, was accosted by an English lady back from Uganda. She asked whether she could be in the light with him, that is, whether he would allow her to point out one or two of his shortcomings, after which he was entirely reinstated to fellowship with her (Barrington-Ward 2012:54). In spite of the fact that this practice of public confession is dying, as noted by Karanja (2012:146), it is still one of the most cherished ways to explicate the principle of a daily walk in the light.

Indeed, 'walking in the light' has become a catchphrase among the members of the EARM. For example, in Kenya, they are often referred to in Kiswahili as watu wa nuru [people of the light]. In fact, a slot has always been given during weekly revival fellowships for members to shed light. That is to confess to one another the sins of the previous week. The phrase has also been used within the EARM as a way of enlightening each other about the coming events. However, the formal statement is what mostly describes the Brethren concerning the practice of a daily walk with the Lord, that is, a life of daily sanctification. Such an experience, in the eyes of the Brethren, invariably describes a saved person.

Hooper (2007:87) states that the EARM expects a saved person to daily yield to the Holy Spirit and Christ by faith. This habit of yielding or brokenness in the daily walk with God, in the power of Jesus' cleansing blood and with the mediation of the Holy Spirit, influences an abiding attitude of prayer and crying to God (Hooper 2007:88) 'Abba, Father', in what looks like real communion with God ( $\mathrm{Rm}$ 8:15f.).

Further, Senyonyi (2013:8) states that the revivalists have dire need to unmask anything that could prejudice their freedom to share their walk with God. They believe that if they walk in the light as God is in the light, Jesus Christ's blood will cleanse them from all sin (1 Jn 1:7). Indeed, Kariuki (1985:52, 53), one of the early Anglican bishops in Kenya, recalls his interaction with Nsibambi that led to his understanding of Christ as his light and saviour. Indeed, personal light arose out of the belief that revival worked in an individual before it could work in the Brethren fellowship. In consultation with the church, these fellowships sometimes become particularly significant in planning and executing the Brethren's mission among other agenda's. The extent to which walking in the light has been buttressed in the mission of God might require unpacking.

\section{Walking in the light in the missio Dei}

The concept of missio Dei underpins all the socio-ethical teachings of the Bible as far as the EARM's mission of walking in the light is concerned. Wright (2006:357) argues that the ethical challenge to God's people is twofold. On the one hand, it is to recognise the mission of God as the heartbeat of their very existence and on the other to respond in ways that express and facilitate it rather than deny and hinder it. Wright (2006:358) further notes that the Bible's grand narrative is about the mission of God and that it demands appropriate dimensions of ethical response from humanity. Abraham (Gn 22:16-18) serves as a model for the continuing education of his descendants, who must walk in the way of the Lord in righteousness and justice so that God can accomplish the missional purpose of Abraham's election (Wright 2006:358). This is well articulated in Genesis 18:18-19, which expresses a moral agenda for the nations on earth.

Wright (2006:359) singles out Sodom as a model of the fallen world and demonstrates God's response to (judgment on) evildoers, those who negate the way of the Lord. Abraham is posited as a model of God's mission, albeit in the context of the wickedness of Sodom (Wright 2006:360). Wright (2006:363) examines the ethical content of the phrases 'the way of the Lord' and 'doing righteousness and justice'. These two protracted phrases anchor ethical expressions in this section as per the teachings and expectations of the Israelites about Yahweh. They also provide insight into understanding the principal theme, walking in the light in the EARM.

On the one hand, Wright (2006:363) argues the expression 'keeping the way of the Lord' or 'walking in the way of the Lord' was a metaphor used in the Old Testament to contrast with the ways of other gods or the ways of sinners - in this particular case, the way of Yahweh and the way of Sodom. Wright $(2006: 364,365)$ notes that the expression 'walking in the way of the Lord' is mostly used to construe obeying God's command so as to reflect God in human life. That is, doing for your neighbour what God has done for you. 
On the other hand, the expression 'righteousness and justice' speaks of conformity to what is right or expected, rightly expressed as social justice, actual things that you do (Wright 2006:365, 367). This missional ethics concept could further be explicated in two ways. Firstly, mission can be seen as an instrument to dispense release to the oppressed. This understanding arises from the belief that the way of the Lord is to provide righteousness and justice to the downtrodden, against the oppressor. While expressing the importance of ethics in God's mission to bless the nations, Wright (2006:368) contends that ethics sandwiches election and mission. This portrays the missional logic of Genesis 18:19 as effected through Abraham's election, which was anticipated to bring out a community dedicated to the ethical reflection of God's character. Secondly, Wright (2006:369) asserts that God's aim to dispense blessings to the nations is tied to God's ethical demands on the people he has created to be the agent of that blessing. This moral imperative has practical dimensions explicated by missional ethics of practical holiness because 'being holy meant living lives of integrity, justice, and compassion in every area of life' (Wright 2006:373).

\section{Walking in the light within a mission of God's framework}

Because the people of God are called to be a light to the nations, they ought to walk in the light in the transformed lives of a holy people. Thus, the problem that is attended to in this context is that walking in the light has led to categorising one group of Christians as saved while the other is not. This has hampered the mission of the church. The Brethren appear to focus more on the outward conformity exemplified by socio-ethical beliefs and practices than inward compliance achieved through the power of the Holy Spirit. However, a concept of walking in the light is needed that operates within a comprehensive mission framework, which helps the church participate fully in the missio Dei. Indeed, Daugherty (2007:165) argues that if the church's mission is to extend the missio Dei, then it can be nothing short of continuing that embodiment of God in Christ among the people of the world.

However, the missio Dei concept is not primarily an activity of the church but an attribute of the missionary God. Therefore, it is not the church that has the mission but the Triune God. Thus the concept of walking in the light raises a critical question about its place in the Trinitarian God. This is because the Brethren seem to emphasise the centrality of the cross (Christ) while the other members of the Trinity are relegated to the peripheries. Aagaard (1973:13) observes that mission ought to be seen as a movement from God to the world, and the church should be viewed as an instrument for that mission. Indeed, there was no better way for God to exemplify his love for humanity except through the glorious incarnation of his son and our saviour, Jesus Christ. Hence, as partakers of mission in God, Christians are bound to walk in his holiness (in his light).
Because the Bible is about the mission (Wright 2006:29), walking with God is in itself walking in the mission of God. Thus, the biblical concept of walking in the light is without a doubt synonymous with walking with God. This idea is postulated in in both Testaments. Whereas Genesis 5:24 and 6:9 indicate Enoch and Noah had a righteous walk with God, 2 Peter 3:9 shows that believers are to walk in the light of the Lord's return, given the judgment that is coming to the world. So, the Genesis texts are indicative of the status of the walk, which is in the Spirit and perfect. This suggests that God's mission is a way of life of the people of God. Also, Peter's Epistle text brings to the fore the imperative aspect of God's expectations towards humanity with regard to his mission. The declarations seem to indicate a calling of the people of God to a particular vocation whose characteristics demand righteous disposition towards God and his mission. This confirms that God has not left his great commission at the mercy of humanity as he swore to build his missional church (Mt 16:18) (Piper 2001:75). The mission is therefore, as Bosch (1991:390) observes, a movement from God to the world and the church is a vessel for that mission.

In addition, Wright (2006:22-23) argues that if mission is biblically informed and authenticated, then it should underpin the church's committed participation as God's people, at God's invitation and command, in God's mission within the history of God's world for the redemption of God's creation. Therefore, God is the owner of the mission while the church is a participant at the invitation and command of God. Moreover, the fact that Wright (2006:23) mentions the purpose of God's mission as the redemption of his creation fits well with John Piper's (2001:206) conception of the missionary text in John 10:16, which affirms God's missionary purpose of gathering his sheep, or building his church (Mt 16:18) from all the nations. This resonates with Bosch's (1991:390) argument that the church is an instrument of God's love in the world because he is a fountain of love. If this is the case, the church (through which the EARM operates) ought to champion practical holiness by positioning walking in the light into its right perspective in the mission of God.

\section{Evaluation of the East African Revival Movement's walking in the light against the missio Dei}

Thus, specific features that define the EARM's religious identity within a framework of walking in the light help to evaluate the EARM against missio Dei. These features include but are not exclusive to the exposition of scripture, centrality of Christ, public testimony and legalism.

\section{Exposition of the scripture}

The Brethren are ardent readers of the Bible, albeit thematic devotions. They make little attempt at exegesis and thus lack a theological dimension. This seems to have been a historical 
problem whereby some founders of Keswick theology, ${ }^{3}$ like Robert and Hannah Smith, had little or no theological education and training. Thus, the Smiths' mishandling of Romans 6:6 (Naselli 2010:102) consequently amplified higher life messages of a second blessing, leading to a religious hypocrisy (Pollock 1964:36). Though the EARM did not embrace the teaching of a second blessing, it nevertheless inherited their literal approach to scriptural interpretation, oblivious to the context. The reading of the Ephesian 5:14 has been blamed for the split in the EARM (Nthamburi 1991:117), resulting in some members aligning to Arise and others to Stand factions.

According to Bosch (1991:426), the historical world is a constitutive element in the understanding of mission and not just a peripheral state for the church's mission. Moreover, Wright (2006:279) argues against spiritualising interpretations, particularly the typological method of relating the Old Testament to the New Testament as if the Old Testament merely foreshadows the New Testament, thus losing its historical significance. The Bible shows that when it is read correctly, it challenges readers to recognise their participatory role in God's mission and to avoid the Pharisaic hypocrisy of religious justification.

Historical-critical scholarship could be a formidable mission tool to help members of the EARM in the biblical application to participate fully in God's mission. It is by so doing that we shall agree with Paul's sentiments: 'I, therefore, the prisoner of the Lord, beseech you that you work worthy of the vocation where you have been called' (Eph 4:1). This realisation is essential because the success of the church's mission is the Lord's work, done the Lord's way. Indeed, a successful mission of the church must be found at the cross of Christ.

\section{Centrality of the cross}

The Brethren's emphasis on the cross of Christ as the basis of their salvation no doubt puts evangelical Christian orthodoxy into its right perspective of proclaiming the gospel and calling the world to repentance and faith. Wright (2006:314) argues that the cross was the inevitable cost of God's whole mission and the unavoidable centre of our mission because all Christian mission flows from the cross. Thus, the centrality of Christ in the salvation of the world provides a critical link for the missio Dei in the Old and New Testaments.

Osborn (2000:87) observes that the overriding theme of the revival meetings and Keswick conventions were the messages of sin, repentance and forgiveness by the blood of Christ. Osborn further states that Joe Church and his associates were said to preach only the crucified Christ (2000:87). Senyonyi (2013:4), a Ugandan Brethren scholar, has been specific about Revivalists' statements about the centrality of Jesus in their preaching and teachings, based on the belief that Jesus paid

3.According to Naselli (2008:29), this phrase denotes 5 days of progressive teaching comm commonly referred to as 'spiritual clinic. Naselli (2008:29) further contends that this teaching characterised early Keswick conventions (1875-1920), which had stereotyped sequence. the price for their sins. Thus, the name Jesus and the cross have been viewed synonymously. The Brethren pray to the Holy Spirit to show them only Jesus because to them real revival is walking with Jesus, victoriously, moment by moment, day by day. However, when this spirituality is viewed from the perspective of missio Dei, it seems to lack balance. Wright (2006:315) claims that the cross must permeate both social and evangelistic engagements. Although the EARM appears to understand this to the fullest, their application of it tends to lean inwardly towards self rather than outwardly towards those outside their camp. Thus, it tends to fall short of a holistic mission informed by a comprehensive mission of the cross.

Bosch (1991:390) also observes that following the Willingen Conference of 1952, the mission came to be understood as flowing from the very nature of God, thus Trinitarian. There is no doubt that God affirmed his supremacy in missions by confirming the supremacy of his son, Jesus Christ, as the conscious centre of the church (Piper 2001:133). Thus, the EARM's Christocentric emphasis could be understood in that perspective. However, it becomes a problem when the Trinitarian thrust of mission appears blurred within the revival fellowships that mostly focus on one member of the Trinity. Bosch (1991:390) observes the doctrine of the missio Dei as God the father sending the Son, and the Father and the Son sending the Spirit, and the Father, the Son and the Holy Spirit sending the church into the world. Thus, a movement towards Trinitarian worship and holistic mission needs to be encouraged as a new model in the EARM's theology of mission. This realisation should not only pervade the Brethren's worship pattern but should also be the basis of their public testimony.

\section{Public confession of sins}

We have seen that public confession of sins is rooted in both scripture and African cultural practices. In both cases, it has earned its place in the light of setting norms and boundaries against which the law is breached and cleansing and confession required. It has been a common practice in the EARM to give public testimony or confession. The Brethren believe that by expunging their misdeeds openly, they will clear their conscience not only before God but humanity as well. Winter (2010:183) observes that it is paramount for people to witness the glory of God in the lives of believers as a reason to turn away from evil to God. Perhaps that could be one of the reasons the Brethren seek to confess their sins openly so that others can see and glorify God.

One of the primary scriptural passages that appear to approve public confession is James 5:16. Whereas it is right to seek assembly of the saints for confession, the amount of publicity given depends upon how public the sin was (Mt 18:15-17). If the sin is publicly known, then to specify it during public confession is a matter of the responsible ethics of a good neighbour. However, as Price (2017:Online) argues, wisdom should be used in declaring the sin - not so much because it might seem disgraceful to tell exactly what the sin 
was but to spare the sinner unnecessary hardship over a sin he has repudiated. It is a good rule of scripture to say that sin should be explicitly confessed to the extent that knowledge of sin exists. This could be a real mission emphasis because it handles the complexities that could arise in the church where a public sin goes unacknowledged. Indeed, because human mission has no life of its own, except in the hands of the sending God who is the initiator of missionary enterprises (Bosch 1991:390), acknowledging public sin is a welcome mission factor. If the Brethren could be discreet in handling various sins, informed legalism could help participation in the missio Dei.

\section{Legalism}

The members of the EARM display passion for God in their conventions and fellowship meetings as they achieve experiential sanctification in their lives. This practical holiness, blended with Keswick theology, has not only been contextualised in the EARM but has also acquired socioethical dimensions. There is nothing wrong with being ethical. However, the moral problem has been viewed from the perspective of creating two categories of Christians in the EARM based on the beliefs and practices of walking in the light, hedged with dos and don'ts. Langley and Kiggins (1974:202) observe that conformity to an accepted pattern of behaviour becomes the gauge for one's religious commitment and this displaces the gospel of God's love and grace. Thus legalistic tendencies ensue ${ }^{4}$ - do not drink; do not smoke; do not wear short skirts; do not take bank loans; do not receive or give a dowry. From this viewpoint, walking in the light is not within the precepts of the mission of God. Bosch (1991:390) claims that human mission has no life of its own, except in the hands of the sending God, who is the initiator of missionary enterprises.

Moral transformation by all definitions is not a problem in itself but in the way it has been applied or misapplied within a framework of community rules of living vis-à-vis the biblical framework of an ethical community. Wright (2006:364) images ethical obedience from the perspective of walking in the ways of the Lord, as to reflect God in the relationship between a just human life and an ethical community. Therefore, the concept of walking with God is a practice that all godly, loving people ought not only to envy but also strive to achieve. Unfortunately, it seems that the ensuing ethical obedience has created a wedge in the EARM. This ethical and divisive attitude appears to put more emphasis on outward moral conformity as expressed in walking in the light at the expense of the Gospel and mission of Christ.

As earlier stated, the Brethren's moral formation provides for evangelism and social responsibility but falls short of replicating the same to those outside their camp. Unlike the past, when evangelism and Christian social action went together (Langley \& Kiggins 1974:201), it is mostly not the

4.See Keswick teachings against indulgence or amusements like beer, theatre, dance, tobacco and questionable employment. Anything done to please the self apart from
Christ as master and lord and neighbour in all things lawful was discouraged Christ as master and lord
(Pierson 1907:91, 93, 94). case currently as exemplified by Mfuko ya Bwana - the Lord's Bag (Mambo 1973:115). The Lord's Bag has been exclusively for the Brethren's activities oblivious of the general need in the church. David Bosch (2011:418) argues for justice to evangelism and social responsibility in dispensing the promises and gifts of the kingdom of God. Thus, there is a need for a paradigm shift from the prevailing socio-ethical informed morality to a gospel-focused mission because, as Wright (2006:390) argues, the mission of the church includes both verbal proclamation and ethical living. We must not conform to the world in any way (Rm 12:1-2); we must be careful; just because the majority of the EARM accept certain ethical behaviours ${ }^{6}$ within their camp does not mean that it is right in the light of missio Dei. Indeed, missio Dei requires behaviours that are inclusive - for example, worship styles that allow the use of public musical systems and dancing in the Spirit; flexible ways of giving testimony; a dress code and hairstyles that depict freedom with responsibility; embracing social welfare activities like bank loans and brotherly-sisterly coexistence.

Further, if a person is not a regular member of Brethren fellowships, he or she may be labelled as not saved because salvation is understood and expressed through walking in the light. From this viewpoint, walking in the light is not within the precepts of the mission of God. Bosch (1991:390) claims that human mission has no life of its own, except in the hands of the sending God, who is the initiator of missionary enterprises.

\section{Conclusion}

In this article the EARM has been evaluated against the missio Dei and to define the movement's religious identity. The article has endeavoured to elucidate the concept of walking in the light and has placed it in the context of missio Dei. It has evaluated the EARM against missio Dei and has established the outstanding features that buttress the EARM.

Further, the article noted that the EARM has not only contextualised much of its inheritance from Keswick theology but also seems to have gone a notch higher in its expression of practical holiness. The socio-ethical beliefs and practices of walking in the light appear to underpin the boundaries within which the saved ones trace their daily walk with God.

Following the above proposed outcomes, the following insights can be learned from this narrative:

1. It will be an exercise in futility if those who achieve practical holiness through the dictums of walking in the light are not faithful participants in missio Dei.

2. It is critical for us to work towards godly driven missionary tasks because the mission of God does not follow us, but we should follow or participate in the mission of God.

5.A fund contributed by the Brethren according to their ability to assist with the organising of conventions and other social needs among the Brethren.

6.Some ethical behaviours include not drinking alcohol, not smoking, not parting your hair, not wearing short skirts, not keeping beards, not borrowing money from the bank, not keeping dogs and not accepting dowry. 
3. If we can shelve our self-interest to express salvation within the covenant of grace, then our faithful participation in the missio Dei is conceivable.

4. We should respond to God's call to worship in the truth and in the Spirit in fruitfulness and abundance within the confines of the great commission.

5. A holier-than-thou predisposition should be replaced with a self-effacing or modest conceptualisation of conversion and worship style, which informs the beliefs and practices of our walk in the light.

\section{Acknowledgements Competing interests}

The authors declare that they have no financial or personal relationships which may have inappropriately influenced them in writing this article.

\section{Authors' contributions}

This article forms part of the PhD thesis of R.K.M. J.J.K. performed the role of the study leader.

\section{References}

Aagaard, J., 1973, 'Trends in missiological thinking during the sixties', International Review of Mission 62(245), 8-25. https://doi.org/10.1111/j.1758-6631.1973. tb01047.x

Barrington-Ward, S., 2012, 'The revival through CMS eyes', in K. Ward \& E. Wild-Wood (eds.), The East African revival: History and legacies, pp. 53-60, Ashgate Publishing Limited, Farnham, England.

Bosch, D.J., 1991, Transforming mission: Paradigm shifts in theology of mission, 7th edn., Orbis Books, Maryknoll, NY.

Bosch, D.J., 2011, Transforming mission: Paradigm shifts in theology of mission, 20th edn., Orbis Books, Maryknoll, NY.
Bruner, J., 2012, 'Public confession and the moral universe of the East African revival', Studies in World Christianity 18(3), 254-268. https://doi.org/10.3366/swc.2012.0024

Daugherty, K., 2007, 'Mission Dei: The trinity and Christian missions', Evangelica Review of Theology 31, 151-168.

Gitari, D., n.d., Paper on East African revival, Embu, Kenya.

Hooper, E., 2007, 'The theology of trans-Atlantic evangelicalism and its impacts on the East African revival', Evangelical Review of Theology 31(1), 71-89.

Karanja, J., 2012, 'Confession and cultural dynamism in the revival', in K. Ward \& E. Wild-Wood (eds.), The East African revival: History and legacies, pp. 144-151, Ashgate Publishing Limited, Farnham, England.

Kariuki, O., 1985, A bishop facing Mount Kenya: An autobiography 1902-1978, Uzima Press, Nairobi.

Langley, M. \& Kiggins, T., 1974, A serving people: A textbook on the church in East Africa for the East African Certificate of Education, Oxford University Press, Nairobi.

Mambo, G.K., 1973, 'The revival fellowship (Brethren) in Kenya', in D.B. Barrett et al. (eds.), Kenya Churches Handbook: The development of Kenyan Christianity, 1498-1973, pp. 110-117, Evangel Publishing House, Kisumu, Kenya.

Naselli, A.D., 2008. Keswick Theology: A Survey of the Doctrine of Sanctification in the Early Keswich Movement, Detroit theological Seminary, Detroit.

Naselli, A.D., 2010, Let go and let God? A survey and analysis of Keswick theology, Lexham Press, Bellingham, WA.

Nthamburi, Z., 1991, From mission to church: A handbook of Christianity in East Africa, Uzima Press, Nairobi.

Osborn. H.H., 2000, Pioneers in the East African revival, Apologia Publications, Winchester, UK.

Pierson, A.T., 1907, 'The message: “Its Practical Application”', in C.F. Harford (ed.), The Keswick convention: Its message, its method, and its men, pp. 89-96, Marshal Brothers Keswick House, Paternoster Row, EC, London.

Piper, J., 2001, Let the nations be glad! The supremacy of god in missions, Inter-Varsity Press, Nottingham, England.

Pollock, J.C., 1964, The Keswick story: The authorized history of the Keswick convention, Hodder \& Stoughton, London.

Price, J.R., 2017, Bible answers, viewed 09 September 2017, from http://www. bibleanswer.com/confssin.htm

Senyonyi, J., 2013, 'GAFCON EA revival distinctives: East African revival. A brief history, its beliefs, and practices', A paper presented during GAFCON Meeting in Nairobi, Kenya, 21 October, pp. 1-9.

Ward, K. \& Wild-Wood, E. (eds.), 2012, The East African revival: History and legacies, Ashgate Publishing Limited, Farnham, England.

Winter, R.D., 2010, 'The future of evangelicals in mission', in D.J. Hesselgrave \& E. Stetzer (eds.), Mission shift: Global mission issues in the third millennium, pp. 164-191, B \& H Publishing Group, Nashville, TN.

Wright, C.J.H., 2006, The mission of God: Unlocking the Bible's grand narrative, Inter-Varsity Press, Nottingham, England. 